\title{
Photosynthetic Acclimation, Biomass Allocation, and Water Use Efficiency of Garlic in Response to Carbon Dioxide Enrichment and Nitrogen Fertilization
}

\author{
Lloyd L. Nackley \\ Department of Plant Sciences, University of California, Davis, CA 95616 \\ Jig Han Jeong \\ School of Environmental and Forest Sciences, University of Washington, Seattle, WA 98195 \\ Lorence R. Oki \\ Department of Plant Sciences, University of California, Davis, CA 95616 \\ Soo-Hyung Kim ${ }^{1}$ \\ School of Environmental and Forest Sciences, University of Washington, Seattle, WA 98195
}

\begin{abstract}
AdDitional INDEX wORDs. carbon partitioning, gas exchange, plant productivity, downregulation, transpiration, bulbing, Allium sativum

Abstract. Garlic (Allium sativum) is a commercially and culturally important crop worldwide. Despite the importance of garlic, there have been few studies investigating how garlic growth and development will be affected by the atmospheric enrichment of carbon dioxide $\left(\mathrm{CO}_{2}\right)$. A split-plot experiment with $\mathrm{CO}_{2}$ concentrations as main plot and nitrogen (N) fertilization as subplot was carried out to examine the effects of elevated $\mathrm{CO}_{2}$ at (mean $\left.\pm \mathrm{SD}\right) 745 \pm 63 \mu \mathrm{mol} \cdot \mathrm{mol}^{-1}$ across three levels of $\mathrm{N}$ : high-N $(16.0 \mathrm{~mm})$, mid-N (4.0 mM), and low-N (1.0 mM). Three hypotheses were tested: 1) garlic plants will allocate proportionally more biomass to bulb when grown in elevated $\mathrm{CO}_{2}$ compared with the plants grown in ambient $\left.\mathrm{CO}_{2} ; 2\right)$ plants will sustain improved photosynthesis without downregulation in elevated $\mathrm{CO}_{2}$, irrespective of $\mathrm{N}$; and 3) elevated $\mathrm{CO}_{2}$ will improve plant water use efficiency (WUE) across $\mathrm{N}$ fertilization levels. We found that proportional biomass allocation to bulb was not significantly enhanced by $\mathrm{CO}_{2}$ enrichment in garlic. Overall biomass accumulation represented by leaf, stem, and bulb did not respond significantly to $\mathrm{CO}_{2}$ enrichment but responded strongly to $\mathrm{N}$ treatments $(P<\mathbf{0 . 0 0 1})$. Contrary to our hypothesis, photosynthetic downregulation was apparent for garlic plants grown in elevated $\mathrm{CO}_{2}$ with a decrease in Rubisco capacity $(P<0.01)$. Instantaneous leaf WUE improved in response to elevated $\mathrm{CO}_{2}(P<0.001)$ and also with increasing $\mathrm{N}$ fertilization $(P<0.001)$. Finally, our results indicate that bulbing ratio is likely to remain unchanged with $\mathrm{CO}_{2}$ or $\mathrm{N}$ levels and may continue to serve as a useful nondesctructive metric to estimate harvest timing and bulb size.
\end{abstract}

Garlic is an important food crop (Food and Agriculture Organization of the United Nations, 2011) that has been incorporated into cuisines around the world. In addition to its culinary contributions, for millennia garlic has been used medicinally as a remedy for a wide variety of medical conditions (Kik et al., 2001; Rivlin, 2006; Tattelman, 2005). Multiple books and reports have been written detailing optimal garlic horticulture (Andrews, 1998; Meredith, 2008) in regard to $\mathrm{N}$ fertilization (Bertoni et al., 1992; Buwalda, 1986) and water inputs (Villalobos et al., 2004). For example, Buwalda and Freeman (1987) reported that the $\mathrm{N}$ fertilization rate of $120 \mathrm{~kg} \cdot \mathrm{ha}^{-1}$ yielded highest harvestable bulb yield under a field condition. Despite the economic and cultural importance of garlic, there have been few studies investigating garlic growth and development in

Received for publication 28 Dec. 2015. Accepted for publication 19 May 2016. This work was supported by a Cooperative Research Program for Agricultural Science and Technology Development (project no. PJ01000707), Rural Development Administration, Republic of Korea.

We thank Zeesoo Han for her assistance with data collection and crop management, and Bruno Pitton and Jared Sisneroz for helpful comments on earlier drafts of the manuscript.

${ }^{1}$ Corresponding author. E-mail: soohkim@uw.edu. future environmental conditions predicted with global environmental change, in particular the atmospheric enrichment of $\mathrm{CO}_{2}$. One of the most consistent responses to $\mathrm{CO}_{2}$ enrichment has been an increase in biomass and total nonstructural carbohydrates in plant tissues (Körner, 2000). As we prepare to adapt crop management to predicted elevated $\mathrm{CO}_{2}$ concentrations (Ziska et al., 2012), it is particularly important to understand how $\mathrm{CO}_{2}$ enrichment will affect carbon allocation to the belowground storage structures for garlic, and other valued crops that form bulbs, corms, or rhizomes.

Extensive research has demonstrated that atmospheric enrichment of $\mathrm{CO}_{2}$ will stimulate photosynthetic responses for $\mathrm{C}_{3}$ plant growth. However, the substantial increases in net photosynthesis immediately after doubling $\mathrm{CO}_{2}$ are typically unsustainable as a consequence of decreased photosynthetic capacity (Leakey et al., 2009; Sage, 1994; Sage et al., 1989). This unsustained stimulation of photosynthesis is thought to be an acclimation response to high $\mathrm{CO}_{2}$ environment as a result of decreased Rubisco activity (Faria et al., 1996; Vu et al., 2008) and is often accompanied with an accumulation of nonstructural carbohydrates and the dilution of $\mathrm{N}$ illustrated by a higher $\mathrm{C} / \mathrm{N}$ ratio (Stitt, 1991; Stitt and Krapp, 1999). This feedback inhibition, 
known as the "carbon sink limitation hypothesis," ascribes the downregulation of photosynthesis to carbohydrate buildup, which is due to an imbalance between carbohydrate quantity and plant sinks mediated by $\mathrm{N}$ nutrition (Pollock and Farrar, 1996). Carbon assimilated during photosynthesis is competitively partitioned to active sinks, and the stimulating effects of $\mathrm{CO}_{2}$ enrichment on photosynthesis will be negated unless a plant has sufficient sinks with which to store the additional carbohydrates (Paul and Foyer, 2001). Carbon sink limitations may not be marked in plants with large carbon sinks such as bulbs and rhizomes (Kinmonth-Schultz and Kim, 2011), or in trees and other perennial species for which longterm storage of carbon is important for their fitness. In optimal conditions, belowground carbohydrate storage structures have been attributed to sustained photosynthetic capacity throughout the plant life cycle (Monje and Bugbee, 1998). However, row crops, like garlic, grow in a dynamic environment with naturally or induced (e.g., targeted drought) suboptimal conditions.

In suboptimal conditions, there is uncertainty whether assimilated carbon will be allocated to storage, reproduction, or defenses (Bazzaz, 1996). Plants allocate biomass to belowground parts for the acquisition of water and nutrients, and to aboveground parts for the acquisition of light and $\mathrm{CO}_{2}$. It has been reported that when plants are grown in elevated $\mathrm{CO}_{2}$, there is a reduction in the relative investment in leaf areas with a concomitant increase in the partitioning of carbon to belowground carbon sinks (Körner, 2000). Rogers et al. (1994) suggested that increasing levels of $\mathrm{CO}_{2}$ in the earth's atmosphere will positively affect root dry weight, length, diameter, width, and root:shoot ratio. To date, many studies focus on roots as the representative belowground structure (Pendall et al., 2004; Rogers et al., 1992; Volder et al., 2007; Xu et al., 2007) with limited studies examining bulbs, corms, or rhizomes. However, the current practices of categorizing plant tissues by location (i.e., belowground structures) may be misleading because these structures are morphologically and anatomically distinct, which may result in diverse physiological responses. For instance, fleshy leaf scales are the primary storage tissues for garlic, whereas the root cortex is the primary storage organ for carrot (Daucus carota). Questions remain whether plants will prioritize growth or development of long-term reserves when atmospheric $\mathrm{CO}_{2}$ supplies are abundant, but other resources such as nutrients or water may be limiting.

Little is known about the link between anatomical and morphological aspects of storage structures and biomass partitioning at the whole plant level under elevated atmospheric $\mathrm{CO}_{2}$ concentrations (Ziska and Bunce, 2006), and how carbon assimilation and allocation responses in high $\mathrm{CO}_{2}$ are related to $\mathrm{N}$ availability in bulb-producing plants. The objectives of this study were to determine photosynthetic responses, patterns of biomass allocation to bulbs, and WUEs of garlic plants grown in elevated $\mathrm{CO}_{2}$ across a range of $\mathrm{N}$ levels. Specifically, our hypotheses consisted of the following: 1) garlic plants will allocate proportionally more biomass to bulb, a storage structure consisting of modified leaves, when grown in elevated $\mathrm{CO}_{2}$ compared with the plants grown in ambient $\mathrm{CO}_{2}$;2) garlic plants will sustain improved photosynthesis with little downregulation in elevated $\mathrm{CO}_{2}$ irrespective of $\mathrm{N}$ supply due to increased sink strength represented by large bulb size; and 3) elevated $\mathrm{CO}_{2}$ will improve plant WUE across $\mathrm{N}$ fertilization levels.

\section{Materials and Methods}

Plant materials and facilities. An Asiatic hardneck garlic (cv. Korean Mountain) purchased from Filaree Garlic Farm (Okanogan, WA) was used for this study. On 13 Jan. 2011, 60 pots (2.54-L tree pots) were filled with unfertilized, sterilized, potting mix (Sunshine Potting Mix \#2; Sun Gro Horticulture, Vancouver, BC, Canada), and planted with one clove per pot. The pots were then placed on wire tables in a glasshouse located in Seattle, WA, and watered from a hose by hand. Daylight was supplemented in the glasshouse with high-pressure sodium $400-\mathrm{W}$ single-phase bulbs during 0800 to $2200 \mathrm{HR}$. The glasshouse uses natural ventilation, exhaust fans, and evaporative cooling pads to prevent excessive temperatures. After $14 \mathrm{~d}$, all cloves had germinated and the pots were organized into experimental treatment groups.

Experimental Design. Three $\mathrm{N}$ levels and two $\mathrm{CO}_{2}$ levels were used as the experimental treatments. First, the 60 pots were randomly split into three $\mathrm{N}$ groups of 20 pots each. The treatments were three levels of $\mathrm{N}$ delivered as ammonium nitrate delivered as part of a modified Hoagland's liquid fertilizer solution: full strength [high-N (16.0 mM N, 0.224 $\left.\mathrm{g} \cdot \mathrm{L}^{-1}\right)$ ], $1 / 4$ strength [mid-N $\left(4.0 \mathrm{~mm} \mathrm{~N}, 0.056 \mathrm{~g} \cdot \mathrm{L}^{-1}\right)$ ], and 1/16 strength [low-N $\left.\left(1.0 \mathrm{~mm} \mathrm{~N}, 0.014 \mathrm{~g} \cdot \mathrm{L}^{-1}\right)\right]$. The macronutrients were provided as follows: $\left(\mathrm{NH}_{4}\right)\left(\mathrm{NO}_{3}\right), \mathrm{CaCl}_{2} \cdot 2 \mathrm{H}_{2} \mathrm{O}, \mathrm{K}_{2} \mathrm{SO}_{4}$, and $\mathrm{KH}_{2} \mathrm{PO}_{4}$ (concentrations for $\mathrm{K}, \mathrm{Ca}, \mathrm{P}, \mathrm{Mg}, \mathrm{S}$, and $\mathrm{Cl}$ were $6.0,3.0,2.0,3.0,1.0$, and $6.0 \mathrm{~mm}$, respectively). The micronutrients were in the forms of $\mathrm{H}_{3} \mathrm{BO}_{3}, \mathrm{MnSO}_{4} \cdot \mathrm{H}_{2} \mathrm{O}$, $\mathrm{ZnSO}_{4} \cdot 7 \mathrm{H}_{2} \mathrm{O}, \mathrm{CuSO}_{4} \cdot 5 \mathrm{H} 2 \mathrm{O}, \mathrm{H}_{2} \mathrm{MoO}_{4}$, and NaFeDTPA (concentrations of $\mathrm{B}, \mathrm{Mn}, \mathrm{Zn}, \mathrm{Cu}, \mathrm{Mo}$, and Fe chelate were 25, 2.0, $2.0,0.5,0.5$, and $18 \mu \mathrm{M}$, respectively). Only $\mathrm{N}$ levels differed; all other elements were maintained at equal levels between treatments. The treatments were applied when the plants were watered by hand at least once per week for the duration of the experiment. Next, the pots were organized into $\mathrm{CO}_{2}$ treatment groups, "ambient" and "elevated." Five pots from each $\mathrm{N}$ group were randomly placed in one of four $\mathrm{CO}_{2}$ controlled sunlit growth chambers that were located inside the glasshouse. The growth chambers $(100 \times 100 \times 200 \mathrm{~cm})$ were closed-topped, polyvinyl chloride-framed units, surrounded with Mylar polyester sheeting (DuPont Teijin Films, Chester, VA). For additional details of the chamber see Kinmonth-Schultz and Kim (2011). In each chamber, temperature/light sensors (HOBO Pendant Temperature/Light senor; Onset Computer, Bourne, MA) recorded temperature and illuminance (kilolux) every $15 \mathrm{~min}$ for the experimental period January to June (Fig. 1). After the experiment concluded, a quantum sensor (LI-190; LI-COR, Lincoln, $\mathrm{NE}$ ) was installed inside the chambers to measure greenhouse photosynthetic photon flux $\left[P P F\left(\mu \mathrm{mol} \cdot \mathrm{m}^{-2} \cdot \mathrm{s}^{-1}\right)\right]$. The $P P F$ data from the subsequent 2 years (i.e., 2012 and 2013) are also provided herein to illustrate the expected characteristics of the chamber light environment during the 2011 experiment (Fig. 1).

Fans forced air through ventilation ducts from outside the greenhouse into the chambers. Two of the chambers were assigned "ambient" air and received air directly through the pipes from outside. The remaining two were designated as "elevated" and were supplemented with additional $\mathrm{CO}_{2}$ that was added to the ventilation ducts through flexible plastic tubing delivered from a 22.70-kg tank (Praxair, Seattle, WA). The elevated $\mathrm{CO}_{2}$ concentrations were maintained by using 

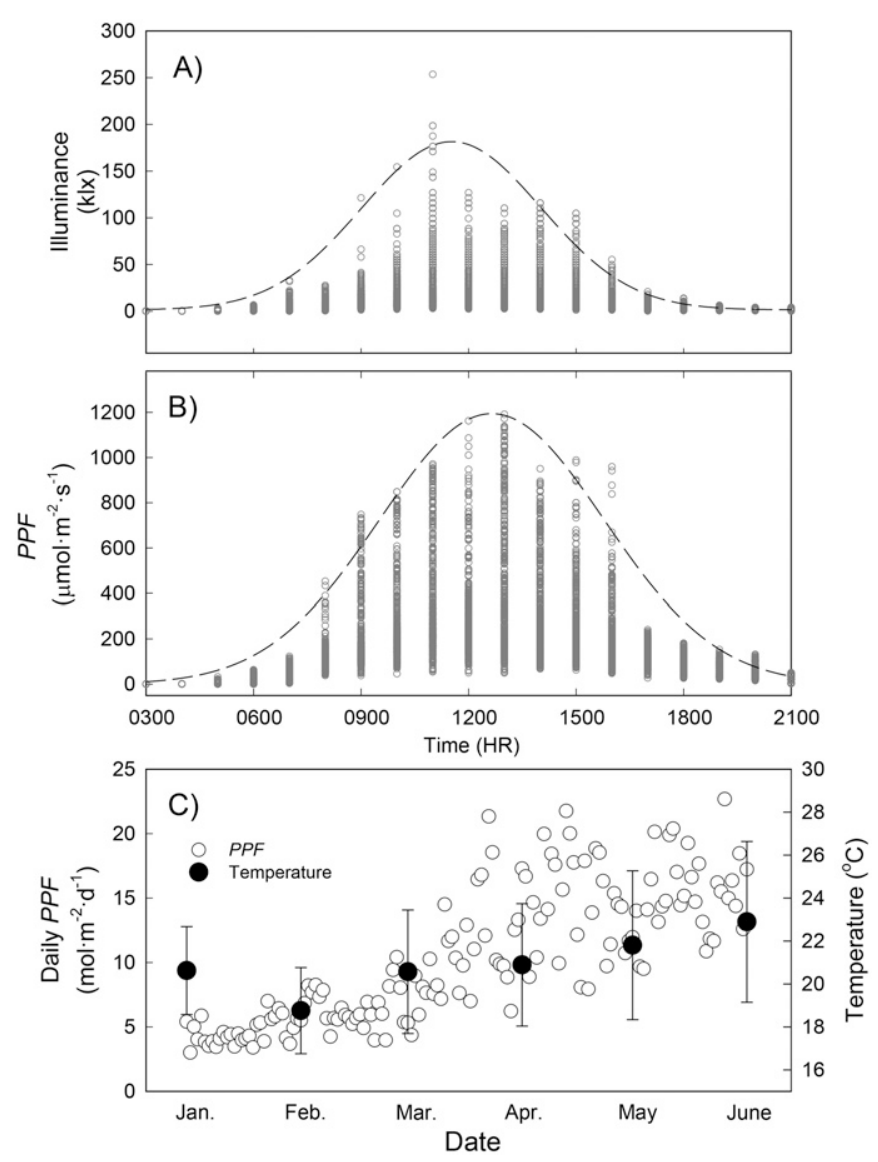

Fig. 1. Diurnal patterns of light inside the sunlit growth chambers. (A) Illuminance data inside the growth chambers during the period of leaf gas-exchange measurements (i.e., May through June 2011). (B) Photosynthetic photon flux $(P P F)$ inside the growth chambers collected during May and June, the 2 years (2012 and 2013) following the experiment (2011). Dashed lines represent regression curves fitted to the maximum hourly values for both data sets. (C) Daily PPF integrals from January through June periods in 2012 and 2013 (open circle); these data are shown as a proxy to represent the $P P F$ patterns at the site during the experimental period in 2011. Also shown are monthly temperature averages with SD error bars (closed circle) inside the growth chambers.

bubble flow meters (FL-2000; Omega, Stamford, CT). $\mathrm{CO}_{2}$ concentrations were automatically measured, every $15 \mathrm{~min}$, by sampling air from within the chambers through an infrared gas analyzer (IRGA) (CIRAS-1; PP Systems International, Amesbury, MA). The CIRAS-1 IRGA has two channels to detect $\mathrm{CO}_{2}$ concentrations, reference (ref.) and differential (diff.). We were able to continuously monitor both of the "elevated" $\mathrm{CO}_{2}$ chambers by connecting a flexible plastic tubing from the two chambers to the ref. and diff. ports. Once a week, for the duration of the experiment, the CIRAS- 1 was taken to an adjacent laboratory and was calibrated against two gas cylinders of certified $\mathrm{CO}_{2}$ concentrations $\left(0\right.$ and $\left.700 \mu \mathrm{mol} \cdot \mathrm{mol}^{-1}\right)$. The "ambient" $\mathrm{CO}_{2}$ was measured, every $15 \mathrm{~min}$, with a sensor (Carbocap GMP242; Vaisala, Vantaa, Finland) placed in one of the "ambient" chambers. The daily mean value with SD for the "elevated" treatment was (mean $\pm \mathrm{sD}) 745 \pm 63 \mu \mathrm{mol} \cdot \mathrm{mol}^{-1}$ of $\mathrm{CO}_{2}$. The mean "ambient" chamber concentration was recorded at $437 \mu \mathrm{mol} \cdot \mathrm{mol}^{-1}$ of $\mathrm{CO}_{2} \cdot \mathrm{CO}_{2}$ and temperature data were stored automatically in a data-logger (CR1000; Campbell Scientific, Logan, UT). To summarize, there were 10 pots from each $\mathrm{N}$ treatment in each of the two $\mathrm{CO}_{2}$ treatments.
LeAF GaS eXChange MEASUREMENTS. A portable photosynthesis system with a leaf chamber fluorometer (LI-6400-40, LI-COR) was used to measure the net $\mathrm{CO}_{2}$ assimilation rates $\left[A\left(\mu \mathrm{mol} \cdot \mathrm{m}^{-2} \cdot \mathrm{s}^{-1}\right)\right]$, and transpiration $\left[E\left(\mathrm{mmol} \cdot \mathrm{m}^{-2} \cdot \mathrm{s}^{-1}\right)\right]$, as well as the differences between atmospheric $\left(C_{\mathrm{a}}\right)$ and internal $\left(C_{\mathrm{i}}\right) \mathrm{CO}_{2}$ concentrations. Gas exchange data were collected on fully expanded young leaves from six to eight randomly selected plants per treatment group $\left(\mathrm{CO}_{2} \times \mathrm{N}\right)$. All gas exchange measurements were allowed 5-7 min to stabilize, light intensity $(P P F)$ was set at $1500 \mu \mathrm{mol} \cdot \mathrm{m}^{-2} \cdot \mathrm{s}^{-1}$, the flow rate was set to $300 \mu \mathrm{mol} \cdot \mathrm{m}^{-2} \cdot \mathrm{s}^{-1}$, and the chamber block temperatures were set to 15 or $25{ }^{\circ} \mathrm{C}$, reflective of the mean daily temperature range (Fig. 1). Gas exchange measurements were recorded at these settings across a range of $C_{\mathrm{a}}$ levels from 50 to $1500 \mu \mathrm{mol} \cdot \mathrm{mol}^{-1} \mathrm{CO}_{2}$. These gas exchange measurements were collected from 1 May 2011, through 12 June 2011, between 0800 and $1400 \mathrm{HR}$. These $\mathrm{CO}_{2}$ responses (i.e., $A-C_{\mathrm{i}}$ ) data were used to determine the presence and extent of photosynthetic acclimation to elevated $\mathrm{CO}_{2}$ (Sage, 1994). Briefly, Rubisco capacity $\left(V_{\text {cmax }}\right)$, maximum rate of electron transport $\left(J_{\max }\right)$, and $A_{\text {elev }} / A_{\text {ambi }}$ (the ratio of $A$ of elevated $\left[\mathrm{CO}_{2}\right]$ grown leaves over $A$ of ambient $\left[\mathrm{CO}_{2}\right]$ grown leaves) at multiple $C_{\mathrm{i}}$ values were estimated to test for photosynthetic downregulation under elevated $\mathrm{CO}_{2}$ conditions (for detailed methods see Kim and Lieth, 2003; Kinmonth-Schultz and Kim, 2011; Sharkey et al., 2007). In addition, $A$ and WUE were compared for all $\mathrm{CO}_{2} \cdot \mathrm{N}$ treatments. WUE was evaluated with the IRGA by comparing instantaneous WUE $(A / E)$, as well as the $C_{\mathrm{i}} / C_{\mathrm{a}}$ ratio. The $C_{\mathrm{i}} / C_{\mathrm{a}}$ ratio reflects the balance between net assimilation and stomatal conductance $\left(g_{\mathrm{S}}\right)$; whereas $A / E$ reflects the amount of carbon gained per water lost. In addition, carbon isotopes $\left({ }^{13} \mathrm{C},{ }^{12} \mathrm{C}\right)$ compositions were analyzed from leaf samples to indicate longterm internal regulation of carbon uptake and water loss.

The carbon isotope discrimination $\left(\delta{ }^{13} \mathrm{C}\right)$ was evaluated from five randomly selected plants from each treatment group. Leaves of these plants were milled through 1-mm mesh screen using a Wiley mini-mill (Thomas Scientific, Swedesboro, NJ). The pulverized leaf samples were then processed at the University of California at Davis stable isotope laboratory with an elemental analyzer (PDZ Europa ANCA-GSL elemental analyzer; Sercon, Irvine, UK) interfaced to a continuous flow isotope ratio mass spectrometer (PDZ Europa 20-20 isotope ratio mass spectrometer, Sercon). Farquhar and Richards (1984) proposed the use of $\Delta$ as a measure of the carbon isotope discrimination by the plant as shown below:

$$
\Delta(\text { discrimination })=\frac{(\delta \text { air }-\delta \text { plant })}{(1+\delta \text { plant })}
$$

The $\mathrm{CO}_{2}$ tanks were filled with gas that was captured during fossil fuel refining, which had been measured (Nackley et al., 2014) as having a different isotopic signature $\left(\delta^{13} \mathrm{C}\right.$, $-35.5 \%$ ) compared with atmospheric $\mathrm{CO}_{2}\left(\delta^{13} \mathrm{C},-8 \%\right)$. As previously stated, the supplemental gas was used to elevate the $\mathrm{CO}_{2}$ concentration from ambient levels $\left(\approx 390 \mu \mathrm{mol} \cdot \mathrm{mol}^{-1}\right)$ to $745 \mu \mathrm{mol} \cdot \mathrm{mol}^{-1}$. Therefore, the air within the elevated chambers was composed of $52 \%$ of the $-8 \%{ }^{13} \mathrm{C}$ air and $48 \%$ of the $-35.5^{\circ} \delta^{13} \mathrm{C}$ gas from the tanks creating an atmosphere with an isotopic composition of $-21.2 \% \delta^{13} \mathrm{C}$ chamber. Although the ambient $\mathrm{CO}_{2}$ outside of the greenhouse was measured at $\approx 390 \mu \mathrm{mol} \cdot \mathrm{mol}^{-1}$, the average $\mathrm{CO}_{2}$ concentration recorded within the ambient chambers was 
$437 \pm 1 \mu \mathrm{mol} \cdot \mathrm{mol}^{-1}$. Therefore, the isotopic composition of the ambient chambers was $-11.025 \% \delta^{13} \mathrm{C}$.

Biomass GRowth and allocation. The $\mathrm{N}$ and $\mathrm{CO}_{2}$ treatments were applied to the garlic plants for $152 \mathrm{~d}$. The experiment concluded on 14 June 2011, at which point all of the plants were harvested. The harvest involved separating the plants into leaves, stem, bulb, and roots; stem part included pseudostem (i.e., sheath) and scape when present. Because of incomplete separation of roots from media in multiple samples, root biomass was not included in the final analysis. The harvested plant parts were bagged in paper and dried for $48 \mathrm{~h}$ in a forced air oven heated to $80^{\circ} \mathrm{C}$. The oven-dry biomass was weighed and analyzed to compare the effects of $\mathrm{CO}_{2}$ and $\mathrm{N}$ on biomass development and allocation.

Leaf N CONCENTRations aNd C/N Ratio. When the plants were harvested on 14 June 2011, 36 leaf samples were randomly selected for determining leaf $\mathrm{C}$ and $\mathrm{N}$ concentrations $(\mathrm{w} / \mathrm{w})$. These leaves were clipped, bagged, and placed in a forced air oven at $80{ }^{\circ} \mathrm{C}$ for $48 \mathrm{~h}$. The dried leaf samples were then ground with a Wiley mini-mill to fit through a 1-mm mesh. The ground leaf samples were transferred into consumable aluminum capsules and combusted in a pure oxygen environment with a CHN analyzer (model-2400; PerkinElmer, Waltham, MA) to determine $\mathrm{C}$ and $\mathrm{N}$ contents in the leaves.

Data analysis. The experiment constituted a split-plot design with $\mathrm{CO}_{2}$ being the main plot and $\mathrm{N}$ being the subplot. Accordingly, $\mathrm{CO}_{2}$ and $\mathrm{N}$ were considered fixed effects and the chambers (blocks) were treated as random effects. Initially, a linear mixed-effects model was used to determine whether significant variability could be attributed to the chambers. When the chamber effects were not found to be significant $(P>0.05)$, they were removed from further linear models that tested the main effects. Succeeding analyses included two-way analyses of variance, using type III sums of squares, to quantify the main effects and interactions from $\mathrm{CO}_{2}$ and $\mathrm{N}$ for biomass responses, leaf gas exchange, and leaf tissue composition. For leaf gas exchange data analysis, we used the temperature (i.e., 15 or $25^{\circ} \mathrm{C}$ ) as a blocking variable to account for the variability due to different measurement temperatures although no significant differences were found between the two measurement temperatures in all gas exchange parameters with an exception of the rate of transpiration $(E)$, similar to the findings in a previous study (Kim et al., 2013). All statistical analyses were calculated using SAS (version 9.4; SAS Institute, Cary, NC) or R 3.2.1 statistical software (R Development Core Team 2011). SigmaPlot 12.5 (Systat software, San Jose, CA) was used to plot the figures.

\section{Results}

Biomass allocation and LEAF N status. Nitrogen treatments resulted in significant differences in leaf, bulb, and leafstem-bulb (LSB) biomass $[P<0.05$ (Fig. 2)], whereas elevated $\mathrm{CO}_{2}$ produced marginally greater stem biomass $(P=0.08)$. With little response of bulb biomass to elevated $\mathrm{CO}_{2}$, none of the biomass ratios involving bulb (i.e., bulb/leaf, bulb/stem, bulb/LSB) were significant (Figs. 3 and 4); this result suggests that garlic plants did not allocate preferentially more biomass to the bulb when grown in elevated $\mathrm{CO}_{2}$. Similarly, the bulb biomass ratio to LSB or other plant parts did not change in response to $\mathrm{N}$ levels (Figs. 3 and 4). On the other hand, bulb diameter increased with $\mathrm{N}$ level $(P<0.001)$ but bulbing ratio
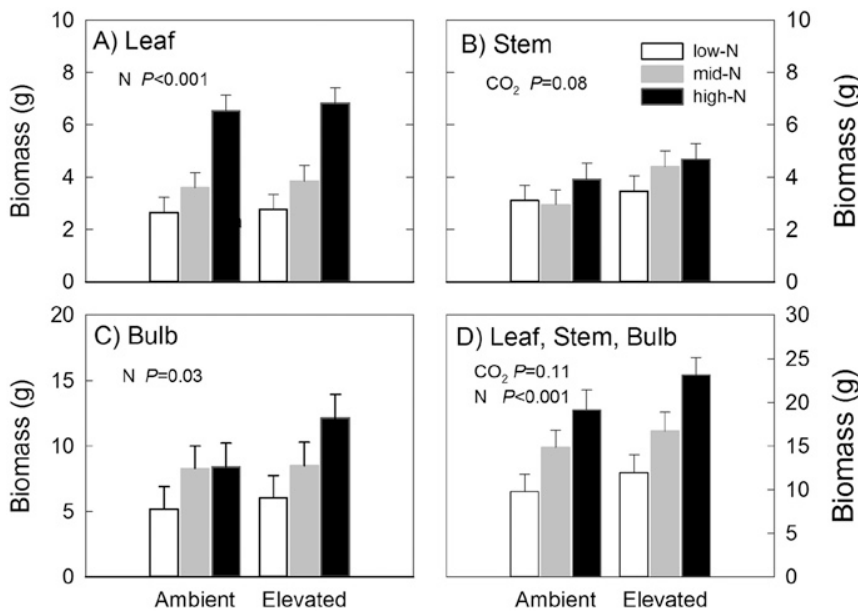

Fig. 2. Biomass by constituent part of garlic plants grown in response to ambient and elevated carbon dioxide at three nitrogen $(\mathrm{N})$ levels: low-, mid-, and high$\mathrm{N}(\mathrm{n}=9-10$, mean $\pm \mathrm{SE})$. (A) Leaf, (B) stem, (C) bulb, and (D) the sum of leaf, stem, and bulb parts.
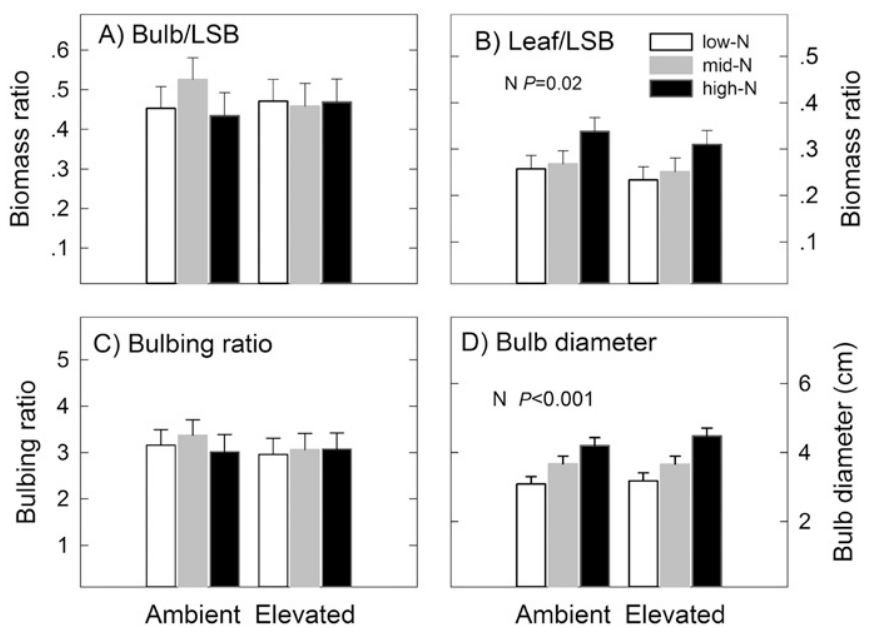

Fig. 3. Biomass ratios in relation to the sum of leaf, stem, and bulb parts (LSB) and bulb characteristics of garlic plants grown in response to ambient and elevated carbon dioxide and nitrogen $(\mathrm{N})$ treatments: low-, mid-, and high-N $(\mathrm{n}=9-10$, mean $\pm \mathrm{SE}$ ). (A) Bulb/leaf-stem-bulb (LSB) biomass ratio, (B) leaf/ LSB biomass ratio, (C) bulb diameter, and (D) bulbing ratio determined as bulb diameter divided by neck diameter.

(bulb diameter/stem diameter) did not change in response to $\mathrm{CO}_{2}$ or $\mathrm{N}$ (Fig. 3). Biomass allocation to leaf increased with $\mathrm{N}$ treatment levels $[P<0.05$ (Fig. 2)].

Leaf $\mathrm{N}$ concentration increased $(P<0.001)$ with $\mathrm{N}$ supply and decreased in response to $\mathrm{CO}_{2}$ enrichment $[P<0.05$ (Fig. 4B)]. Reduction in leaf $\mathrm{N}$ under elevated $\mathrm{CO}_{2}$ was greater when $\mathrm{N}$ supply was the highest as evidenced by a significant interaction $[P<0.05$ (Fig. 4A)]. Leaf $\mathrm{C} / \mathrm{N}$ ratios decreased with increasing $\mathrm{N}$ supply (Fig. 4B) but did not change in response to elevated $\mathrm{CO}_{2}$ treatment.

$\mathrm{CO}_{2}$ ASSIMILATION AND PHOTOSYNTHETIC DOWNREgULATION. As expected for $\mathrm{a}_{3}$ plant, the leaf net $\mathrm{CO}_{2}$ assimilation rate $(A)$ increased with increasing $\mathrm{CO}_{2}$ concentrations $(P<0.05)$ and also with $\mathrm{N}$ levels $[P<0.05$ (Table 1)]. When the LI-6400 leaf chamber was set to $\mathrm{CO}_{2}$ concentrations near the growth $\mathrm{CO}_{2}$ concentrations (i.e., 400 or $700 \mu \mathrm{mol} \cdot \mathrm{mol}^{-1}$ ), $A$ increased by $23 \%$ on average in plants grown in elevated $\mathrm{CO}_{2}$ compared with 
those from the ambient $\mathrm{CO}_{2}$ treatment (Table 1). Similarly, $A$ increased $39 \%$ and $40 \%$ under mid- and high- $\mathrm{N}$ treatments, respectively, compared with low-N treatment (Table 1). This increase in $A$ under elevated $\mathrm{CO}_{2}$ with increasing $\mathrm{N}$ levels is likely to have contributed to a marginal increase in biomass responses (Fig. 2).

The $V_{\text {cmax }}$ was significantly affected by both $\mathrm{CO}_{2}$ and $\mathrm{N}$ treatments $(P<0.01) . \mathrm{CO}_{2}$ enrichment significantly decreased $V_{\text {cmax }}$ rates with the average ambient rates being $\approx 1 / 3$ greater than the Rubisco capacity of the plants grown in elevated $\mathrm{CO}_{2}$ (Table 1). Nitrogen fertilization had a positive relationship with $V_{\text {cmax }}$. The low-N treatment had significantly lower rates than the mid- and high-N treatments at either $\mathrm{CO}_{2}$ treatment level (Table 1). The $\mathrm{CO}_{2}$ effect on $J_{\max }$ was marginal $(P=0.08)$, whereas the $\mathrm{N}$ was found to play a significant role $(P<0.01)$. At either $\mathrm{CO}_{2}, J_{\max }$ was found to be much lower for the low-N treatment compared with the mid- and high-N treatments
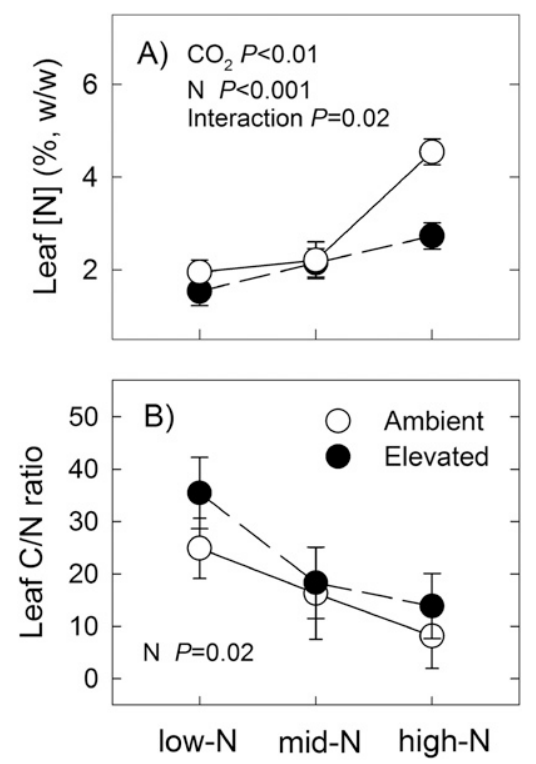

Fig. 4. Leaf $\mathrm{N}$ concentration in garlic plants in response to ambient and elevated carbon dioxide at three nitrogen (N) levels: low-, mid-, and high-N. (A) In \% $(\mathrm{w} / \mathrm{w})$ and $(\mathbf{B}) \mathrm{C} / \mathrm{N}$ ratio $(\mathrm{n}=6$; mean $\pm \mathrm{SE})$.
(Table 1). The $A_{\text {elev }} / A_{\text {ambi }}$ ratios stayed below one in most cases indicating apparent photosynthetic downregulations especially at low intercellular $\mathrm{CO}_{2}$ concentrations in mid- and high-N. The values were more variable when $\mathrm{N}$ supply was low (Fig. 5). Together with a lower $V_{\text {cmax }}$, this result suggests that biochemical downregulation associated with carboxylation efficiency at low $\mathrm{CO}_{2}$ was highly likely present.

INSTANTANEOUS AND LONG-TERM WUE. The leaf gas exchange indicated enhanced instantaneous WUE $(A / E)$ in response to increasing $\mathrm{CO}_{2}[P<0.001$ (Table 1)]. The positive relationship between $\mathrm{N}$ fertilization and WUE (Table 1) is also evidenced by the significant difference in $A / E(P<0.001)$ between $\mathrm{N}$ treatments. In both cases, the improvements in WUE were more attributable to gains by $A$, which were significantly improved by $\mathrm{N}$ and $\mathrm{CO}_{2}$ enrichment, than by the limited differences in $E$, which did not respond significantly to either $\mathrm{CO}_{2}$ or $\mathrm{N}$ treatments (data not shown). The interaction between $\mathrm{CO}_{2}$ and $\mathrm{N}$ on WUE was significant $(P<0.05)$ indicating that instantaneous WUE increased more with $\mathrm{N}$ levels in elevated $\mathrm{CO}_{2}$ than in ambient $\mathrm{CO}_{2}$ conditions. Similar to the instantaneous WUE, the $\Delta^{13} \mathrm{C}$ results were also significantly related to the $\mathrm{CO}_{2}$ treatments $(P<$ 0.001). $\Delta^{13} \mathrm{C}$ results did not indicate an effect from the $\mathrm{N}$ treatment or an interaction between $\mathrm{CO}_{2}$ and $\mathrm{N}$.

\section{Discussion}

Garlic, like other $\mathrm{C}_{3}$ crops, exhibited beneficial responses to both $\mathrm{CO}_{2}$ and $\mathrm{N}$ enrichment. However, the results were not uniform for all plant parts and processes. Specifically, our results did not support our first hypothesis that garlic plants would allocate proportionally more biomass to bulb in response to $\mathrm{CO}_{2}$ enrichment. Although the results indicated that net $\mathrm{CO}_{2}$ assimilation rate $(A)$ was enhanced by $\mathrm{CO}_{2}$ enrichment (Table 1) neither bulb nor leaf biomass responded significantly to elevated $\mathrm{CO}_{2}$. Overall, garlic plant biomass did not increase significantly in response to $\mathrm{CO}_{2}(P=0.11)$ with the stem biomass being marginally responsive $(P=0.08)$ (Fig. 2). Studies that investigated the effects of $\mathrm{CO}_{2}$ enrichment on the growth and biomass of crop species with underground storage organs [e.g., potato (Solanum tuberosum), onion (Allium cepa), carrot, and radish (Raphanus sativus)] reported highly variable biomass accumulation and allocation responses (Jasoni et al.,

Table 1. Leaf gas-exchange parameters $(n=6-8)$ and ${ }^{13} \mathrm{C}$ stable isotope ratios $\left[\Delta^{13} \mathrm{C}\right.$ in $\%$ o $\left.(\mathrm{n}=5)\right]$ of garlic plants in response to carbon dioxide $\left(\mathrm{CO}_{2}\right)$ and nitrogen $(\mathrm{N})$ treatments. Leaf gas-exchange parameters include net $\mathrm{CO}_{2}$ assimilation rates $(A)$, instantaneous leaf water use efficiency (WUE), Rubisco capacity $\left(V_{\text {cmax }}\right)$, and potential electron transport rate $\left(J_{\max }\right)$.

\begin{tabular}{|c|c|c|c|c|c|c|c|c|}
\hline & & Cuvette $\left[\mathrm{CO}_{2}\right]^{\mathrm{z}}$ & $\begin{array}{c}A \\
\left(\mu \mathrm{mol} \cdot \mathrm{m}^{-2} \cdot \mathrm{s}^{-1}\right) \\
\end{array}$ & $\begin{array}{c}\text { WUE } \\
\left(\mu \mathrm{mol} \cdot \mathrm{mmol}^{-1}\right)^{\mathrm{y}}\end{array}$ & $\begin{array}{l}C_{\mathrm{i}} / C_{\mathrm{a}} \\
\text { ratio }^{\mathrm{x}} \\
\end{array}$ & $\begin{array}{c}V_{\mathrm{cmax}} \\
\left(\mu \mathrm{mol} \cdot \mathrm{m}^{-2} \cdot \mathrm{s}^{-1}\right) \\
\end{array}$ & $\begin{array}{c}J_{\max } \\
\left(\mu \mathrm{mol} \cdot \mathrm{m}^{-2} \cdot \mathrm{s}^{-1}\right) \\
\end{array}$ & $\Delta^{13} \mathrm{C} \%$ \\
\hline Growth $\mathrm{CO}_{2}$ & $\mathrm{~N}$ & $\left(\mu \mathrm{mol} \cdot \mathrm{mol}^{-1}\right)$ & \multicolumn{6}{|c|}{$($ mean \pm SE) } \\
\hline Ambient & Low & 400 & $8.7 \pm 1.4$ & $5.6 \pm 0.7$ & $0.73 \pm 0.02$ & $34.7 \pm 4.6$ & $97.0 \pm 9.3$ & $24.4 \pm 1.3$ \\
\hline Ambient & High & 400 & $12.8 \pm 1.5$ & $6.8 \pm 0.7$ & $0.69 \pm 0.03$ & $53.9 \pm 4.3$ & $114.3 \pm 8.9$ & $26.9 \pm 2.6$ \\
\hline Elevated & Low & 700 & $11.1 \pm 1.3$ & $6.6 \pm 0.7$ & $0.79 \pm 0.02$ & $28.7 \pm 4.1$ & $73.2 \pm 8.5$ & $15.2 \pm 2.6$ \\
\hline Elevated & Mid & 700 & $15.5 \pm 1.7$ & $10.1 \pm 0.8$ & $0.74 \pm 0.03$ & $39.5 \pm 4.1$ & $107.6 \pm 8.5$ & $15.8 \pm 3.2$ \\
\hline \multirow[t]{3}{*}{$P>\mathrm{F}$} & $\mathrm{CO}_{2}$ & & 0.034 & $<0.001$ & 0.20 & 0.007 & 0.08 & $<0.001$ \\
\hline & $\mathrm{N}$ & & 0.012 & $<0.001$ & 0.011 & 0.005 & 0.01 & 0.67 \\
\hline & $\mathrm{CO}_{2} \times \mathrm{N}$ & & 0.90 & 0.037 & 0.39 & 0.52 & 0.57 & 0.89 \\
\hline
\end{tabular}

${ }^{\mathrm{z}}\left[\mathrm{CO}_{2}\right]$ of the air inside leaf cuvette $\left(\mathrm{C}_{\mathrm{a}}\right)$ matching daytime growth $\left[\mathrm{CO}_{2}\right]$.

y Instantaneous leaf WUE determined as $A$ divided by the transpiration rate.

${ }^{\mathrm{x}}$ The ratio of internal $\left[\mathrm{CO}_{2}\right]\left(C_{\mathrm{i}}\right)$ over leaf cuvette $\left[\mathrm{CO}_{2}\right]\left(C_{\mathrm{a}}\right)$. 

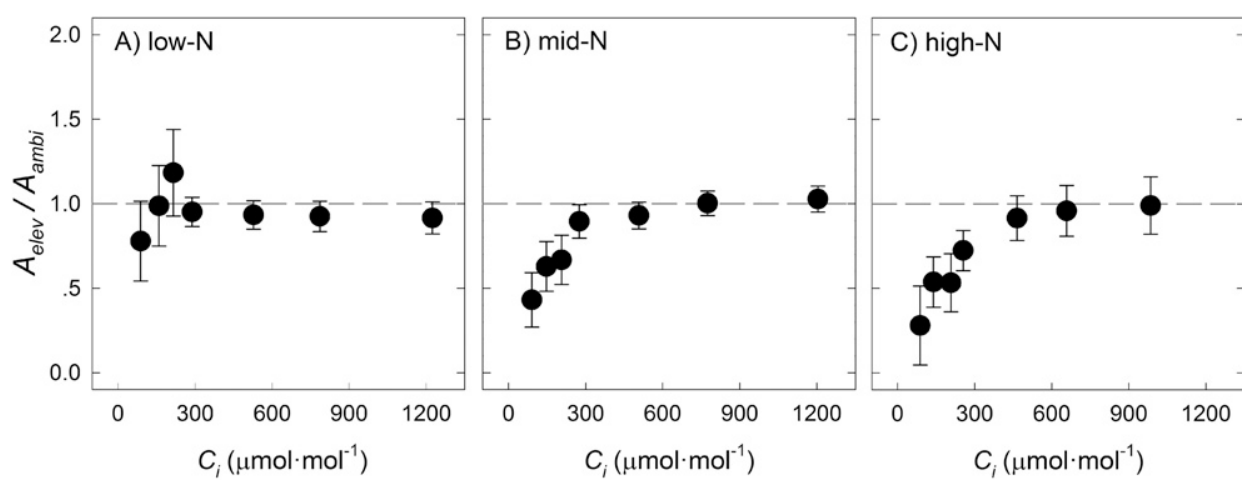

Fig. 5. Photosynthetic acclimation to elevated carbon dioxide $\left(\mathrm{CO}_{2}\right)$ in garlic plants at $(\mathbf{A})$ low-nitrogen $(\mathrm{N})$, (B) mid-N, and (C) high-N. The ratio of net $\mathrm{CO}_{2}$ assimilation rates $(A)$ between elevated and ambient $\mathrm{CO}_{2}$ grown leaves $(\mathrm{n}=6-8$, mean $\pm \mathrm{SE})$ are plotted over $\left[\mathrm{CO}_{2}\right]$ at the intercellular air spaces $\left(C_{\mathrm{i}}\right)$. The ratios $\left(A_{\mathrm{elev}} / A_{\mathrm{ambi}}\right)$ below 1 are indicative of photosynthetic downregulation.

2004; Mortensen, 1994; Schapendonk et al., 2000). For example, Mortensen (1994) reported that the yield of carrot and onion increased under elevated $\mathrm{CO}_{2}$, whereas leek (Allium ampeloprasum) yields were not significantly affected by the $\mathrm{CO}_{2}$ concentration. Further variation was reported by biomass grasses with rhizomes. Like garlic both reed canary grass (Phalaris arundinacea), and giant reed (Arundo donax) showed increased stem biomass and total biomass with elevated $\mathrm{CO}_{2}$ (Kinmonth-Schultz and Kim, 2011; L.L. Nackley, N. Hough-Snee, and S.-H. Kim, unpublished data). Yet, unlike garlic, giant reed had increased allocation to belowground storage organs (L.L. Nackley, N. Hough-Snee, and S.-H. Kim, unpublished data); reed canary grass did not (Kinmonth-Schultz and Kim, 2011).

The observed insignificant biomass response to $\mathrm{CO}_{2}$ enrichment could be an outcome of photosynthetic acclimation to elevated $\mathrm{CO}_{2}$ concentrations. The photosynthetic downregulation has been reported in experiments on other $\mathrm{C}_{3}$ plant species (Sage et al., 1989) including bulbous crops such as onion (Wheeler et al., 2004). In this study, we hypothesized that photosynthetic downregulation under elevated $\mathrm{CO}_{2}$ would be minimal in garlic because of the bulb serving as a strong carbon sink. We evaluated the different gas exchange measurements to discover any potential mechanisms responsible for the growth patterns. When the net $\mathrm{CO}_{2}$ assimilation rate $(A)$ was compared with the respective chamber $\mathrm{CO}_{2}$ conditions (Table 1), after more than 5 months of $\mathrm{CO}_{2}$ enrichment the plants grown in the elevated $\mathrm{CO}_{2}$ chambers had consistently greater net assimilation rates across all $\mathrm{N}$ treatments (Table 1). However, decomposition of the $A-C_{\mathrm{i}}$ curves showed that elevated $\mathrm{CO}_{2}$ decreased carboxylation capacity $\left(V_{\text {cmax }}\right)$ significantly $(P<$ $0.01)$ whereas its effect was marginal on $J_{\max }(P=0.08)$. On the other hand, $J_{\max }$ responded strongly to $\mathrm{N}$ levels $(P<0.01)$. These findings are consistent with other research on impacts of $\mathrm{CO}_{2}$ and $\mathrm{N}$ interactions in photosynthetic downregulations to elevated $\mathrm{CO}_{2}$ (Sims et al., 1998). The greater sensitivity of $V_{\text {cmax }}$ implies that the amount, activation state, and kinetic properties of Rubisco were more responsive to $\mathrm{CO}_{2}$ enrichment compared with the rate of electron transport rate (i.e., $J_{\max }$ ), which did not respond strongly to $\mathrm{CO}_{2}$ enrichment. The $J_{\max }$ is a measure linked to RuBP regeneration rate in the Calvin Cycle, which will depend on energetics, light availability, and photochemistry (Sharkey et al., 2007). These factors were less affected by $\mathrm{CO}_{2}$ enrichment, yet can be significantly affected by $\mathrm{N}$ as shown in our results on $J_{\max }$ (Table 1). The decreased $J_{\max }$ values in the low-N treatment were likely caused by limited availability of the $\mathrm{N}$-dependent molecules in the light reactions of photosynthesis [e.g., chlorophyll, light harvesting complex, electron transport components, and coupling factor (Evans, 1989)]. Our results on $V_{\text {cmax }}$ and $J_{\text {max }}$ suggest that elevated $\mathrm{CO}_{2}$ was likely to have reduced the Rubisco capacity in association with photosynthetic downregulation in garlic (Table 1); this was further corroborated by the reduced $A_{\text {elev }} / A_{\text {ambi }}$ ratios (Fig. 5). It has been pointed out that the biochemical signals of photosynthetic downregulation in response to $\mathrm{CO}_{2}$ enrichment may be influenced by pot-size limitations (Poorter et al., 2012; Sage, 1994). Our plants were not root bound at harvest suggesting that pot size was unlikely to limit belowground sink capacity in our experiment. As discussed by Wullschleger (1993), leaf responses do not always relate to whole plant responses; and it is important to recognize the photosynthesis model parameters (i.e., $V_{\text {cmax }}$ and $J_{\max }$ ) describe the initial fixation of $\mathrm{CO}_{2}$ in the chloroplast by Rubisco, and that the subsequent translocation and allocation of this carbon for the growth of organs is a separate question.

Both leaf gas exchange and ${ }^{13} \mathrm{C}$ stable isotope data supported the hypothesis that elevated $\mathrm{CO}_{2}$ improved WUE of garlic plants across $\mathrm{N}$ treatments (Table 1). The combination of short-term (gas exchange) and long-term $\left(\Delta^{13} \mathrm{C}\right)$ metrics provides us with insights about the mechanics of WUE. The results show that of the WUE parameters, $A / E$ and $\Delta^{13} \mathrm{C}$ were significantly affected by the $\mathrm{CO}_{2}$ treatment, whereas $E$ and $g_{\mathrm{s}}$ alone were not $(P>$ 0.05 ). For many other plants, improved WUE at elevated levels of $\mathrm{CO}_{2}$ has been attributed to partial stomatal closure (Field et al., 1995; Nackley et al., 2014) and subsequently reduced stomatal water loss. In our study, the instantaneous WUE (i.e., $A / E$ ) increased as a result of an increase in photosynthesis rather than a decrease in transpiration (Table 1). The measured conductance and transpiration rates remained unchanged in elevated $\mathrm{CO}_{2}$. Overtime, this increase in $A / E$ is likely to have resulted in an increase in the long-term WUE represented by the decreased $\Delta^{13} \mathrm{C}$ (Table 1). Indication of short- and long-term improvements in WUE suggest that garlic plants will likely gain more carbon per unit water used in elevated $\mathrm{CO}_{2}$ irrespective of soil $\mathrm{N}$ fertility. The importance of gaining more carbon per unit water loss is especially relevant for garlic agriculture in arid and semiarid climates (i.e., California and other Mediterranean climate zones) where climate change has been predicted to increase summer temperatures and decrease fresh water supplies (Giorgi and Lionello, 2008) exacerbating growing season drought (Seager et al., 2013).

Despite the treatment effects on growth and $\mathrm{N}$ content, the bulbing ratio remained consistent (Fig. 3). This result is important considering that the bulbing ratio is a common allometric relationship used by garlic farmers as a nondestructive indicator of harvest time. Our results suggest that the bulbing ratio can continue to be a robust proxy across a range of soil fertility and in light of climate change, because the 
relationship was unaffected by either $\mathrm{N}$ or $\mathrm{CO}_{2}$ treatments (Fig. $3)$. Research shows that optimal garlic harvests are recommended when the foliage collapses and starts to senesce, and when the bulbing ratio is about four or five (Takagi, 1990). When these phenological stages occur, the garlic plants allocate photosynthates to storage carbohydrates including fructans and other metabolites in the bulb. Our values are slightly lower than the recommended bulbing ratio for harvest. This is likely because our final destructive harvest was conducted before the bulbs were completely mature to compare biomass of other plant parts in addition to bulbs.

In summary, our results did not support our first two hypotheses. That is, 1) garlic plants did not allocate proportionally more biomass to bulb when grown in elevated $\mathrm{CO}_{2}$ compared with the plants grown in ambient $\mathrm{CO}_{2}$, whereas other growth and physiological parameters such as stem biomass and $A$ have been increased in elevated $\mathrm{CO}_{2}$ and 2) the $V_{\text {cmax }}$ and $A_{\text {elev }} / A_{\text {ambi }}$ ratios decreased in response to elevated $\mathrm{CO}_{2}$ irrespective of $\mathrm{N}$; this result is a strong indicator of photosynthetic downregulations in response to $\mathrm{CO}_{2}$, irrespective of $\mathrm{N}$. Our third hypothesis was supported as elevated $\mathrm{CO}_{2}$ increased instantaneous WUE and reduced $\Delta^{13} \mathrm{C}$ across $\mathrm{N}$ levels. On the other hand, almost all growth and physiological parameters we tested responded strongly to $\mathrm{N}$ treatments. Our result also indicate that bulbing ratio is likely to remain unchanged with $\mathrm{CO}_{2}$ or $\mathrm{N}$ levels and may continue to serve as a useful metric to determine harvest timing in a changing climate.

\section{Literature Cited}

Andrews, G. 1998. Growing and using garlic. Storey Books, Pownal, VT.

Bazzaz, F.A. 1996. Plants in changing environments: Linking physiological, population, and community ecology. Cambridge Univ. Press, Cambridge, UK.

Bertoni, G., P.C. Soubieille, and J.M. Llorens. 1992. Growth and nitrogen nutrition of garlic (Allium sativum L.) during bulb development. Sci. Hort. 50:187-195.

Buwalda, J.G. 1986. Nitrogen nutrition of garlic (Allium sativum L.) under irrigation, crop growth and development. Sci. Hort. 29:55-68.

Buwalda, J.G. and R.E. Freeman. 1987. Effects of nitrogen fertilisers on growth and yield of potato (Solanum tuberosum L. 'Ilam Hardy'), onion (Allium cepa L. 'Pukekohe Longkeeper'), garlic (Allium sativum L. 'Y strain') and hybrid squash (Cucurbita maxima 'L. Delica'). Sci. Hort. 32:161-173.

Evans, J.R. 1989. Photosynthesis and nitrogen relationships in leaves of $\mathrm{C}_{3}$ plants. Oecologia 78:9-19.

Faria, T., D. Wilkins, R.T. Besford, M. Vaz, J.S. Pereira, and M.M. Chaves. 1996. Growth at elevated CO2 leads to down-regulation of photosynthesis and altered response to high temperature in Quercus suber L. seedlings. J. Expt. Bot. 47:1755-1761.

Farquhar, G.D. and R.A. Richards. 1984. Isotopic composition of plant carbon correlates with water-use efficiency of wheat genotypes. Funct. Plant Biol. 11:539-552.

Field, C.B., R.B. Jackson, and H.A. Mooney. 1995. Stomatal responses to increased $\mathrm{CO} 2$-Implications from the plant to the global-scale. Plant Cell Environ. 18:1214-1225.

Food and Agriculture Organization of the United Nations. 2011. The state of the world's land and water resources for food and agriculture (SOLAW)-Managing systems at risk. Earthscan, Rome, Italy.

Giorgi, F. and P. Lionello. 2008. Climate change projections for the Mediterranean region. Global Planet. Change 63:90-104.

Jasoni, R., C. Kane, C. Green, E. Peffley, D. Tissue, L. Thompson, P. Payton, and P.W. Pare. 2004. Altered leaf and root emissions from onion (Allium cepa L.) grown under elevated $\mathrm{CO}_{2}$ conditions. Environ. Expt. Bot. 51:273-280.
Kik, C., R. Kahane, and R. Gebhardt. 2001. Garlic and health. Nutr. Metab. Cardiovasc. Dis. 11:57-65.

Kim, S.-H., J.H. Jeong, and L.L. Nackley. 2013. Photosynthetic and transpiration responses to light, $\mathrm{CO}_{2}$, temperature, and leaf senescence in garlic: Analysis and modeling. J. Amer. Soc. Hort. Sci. 138:149-156.

Kim, S.-H. and J.H. Lieth. 2003. A coupled model of photosynthesis, stomatal conductance and transpiration for a rose leaf (Rosa hybrida L.). Ann. Bot. (Lond.) 91:771-781.

Kinmonth-Schultz, H. and S.-H. Kim. 2011. Carbon gain, allocation and storage in rhizomes in response to elevated atmospheric carbon dioxide and nutrient supply in a perennial $\mathrm{C}_{3}$ grass, Phalaris arundinacea. Funct. Plant Biol. 38:797-807.

Körner, C. 2000. Biosphere responses to $\mathrm{CO}_{2}$ enrichment. Ecol. Appl. 10:1590-1619.

Leakey, A.D.B., E.A. Ainsworth, C.J. Bernacchi, A. Rogers, S.P. Long, and D.R. Ort. 2009. Elevated $\mathrm{CO}_{2}$ effects on plant carbon, nitrogen, and water relations: Six important lessons from FACE. J. Expt. Bot. 60:2859-2876.

Meredith, T.J. 2008. The complete book of garlic: A guide for gardeners, growers, and serious cooks. Timber Press, Portland, OR. Monje, O. and B. Bugbee. 1998. Adaptation to high $\mathrm{CO}_{2}$ concentration in an optimal environment: Radiation capture, canopy quantum yield and carbon use efficiency. Plant Cell Environ. 21:315-324.

Mortensen, L.M. 1994. Effects of elevated $\mathrm{CO}_{2}$ concentrations on growth and yield of eight vegetable species in a cool climate. Sci. Hort. 58:177-185.

Nackley, L.L., K.A. Vogt, and S.-H. Kim. 2014. Arundo donax water use and photosynthetic responses to drought and elevated $\mathrm{CO}_{2}$. Agr. Water Mgt. 136:13-22.

Paul, M.J. and C.H. Foyer. 2001. Sink regulation of photosynthesis. J. Expt. Bot. 52:1383-1400.

Pendall, E., S. Bridgham, P.J. Hanson, B. Hungate, D.W. Kicklighter, D.W. Johnson, B.E. Law, Y. Luo, J.P. Megonigal, M. Olsrud, M.G. Ryan, and S. Wan. 2004. Below-ground process responses to elevated $\mathrm{CO}_{2}$ and temperature: $\mathrm{A}$ discussion of observations, measurement methods, and models. New Phytol. 162:311-322.

Pollock, J. and C. Farrar. 1996. Source-sink relations: The role of sucrose, p. 262-276. In: N.R. Baker (ed.). Photosynthesis and the environment. Kluwer Academic Publishers, Dordrecht, the Netherlands/ Boston, MA.

Poorter, H., J. Bühler, D. Van Dusschoten, J. Climent, and J.A. Postma. 2012. Pot size matters: A meta-analysis of the effects of rooting volume on plant growth. Funct. Plant Biol. 39:839-850.

Rivlin, R.S. 2006. Is garlic alternative medicine? J. Nutr. 136:713S$715 \mathrm{~S}$.

Rogers, H.H., C. Peterson, J. McCrimmon, and J. Cure. 1992. Response of plant roots to elevated atmospheric carbon dioxide. Plant Cell Environ. 15:749-752.

Rogers, H.H., G.B. Runion, and S.V. Krupa. 1994. Plant responses to atmospheric $\mathrm{CO}_{2}$ enrichment with emphasis on roots and the rhizosphere. Environ. Pollut. 83:155-189.

Sage, R.F. 1994. Acclimation of photosynthesis to increasing atmospheric $\mathrm{CO}_{2}$ : The gas exchange perspective. Photosyn. Res. 39:351368.

Sage, R.F., T.D. Sharkey, and J.R. Seemann. 1989. Acclimation of photosynthesis to elevated $\mathrm{CO}_{2}$ in five $\mathrm{C}_{3}$ species. Plant Physiol. 89:590-596.

Schapendonk, A., M. van Oijen, P. Dijkstra, C. Pot, W. Jordi, and G. Stoopen. 2000. Effects of elevated $\mathrm{CO}_{2}$ concentration on photosynthetic acclimation and productivity of two potato cultivars grown in open-top chambers. Funct. Plant Biol. 27:1119-1130.

Seager, R., M. Ting, C. Li, N. Naik, B. Cook, J. Nakamura, and H. Liu. 2013. Projections of declining surface-water availability for the southwestern United States. Nat. Clim. Change 3:482-486.

Sharkey, T.D., C.J. Bernacchi, G.D. Farquhar, and E.L. Singsaas. 2007. Fitting photosynthetic carbon dioxide response curves for $\mathrm{C}_{3}$ leaves. Plant Cell Environ. 30:1035-1040. 
Sims, D.A., Y. Luo, and J.R. Seemann. 1998. Comparison of photosynthetic acclimation to elevated $\mathrm{CO}_{2}$ and limited nitrogen supply in soybean. Plant Cell Environ. 21:945-952.

Stitt, M. 1991. Rising $\mathrm{CO}_{2}$ levels and their potential significance for carbon flow in photosynthetic cells. Plant Cell Environ. 14: $741-762$

Stitt, M. and A. Krapp. 1999. The interaction between elevated carbon dioxide and nitrogen nutrition: The physiological and molecular background. Plant Cell Environ. 22:583-621.

Takagi, H. 1990. Garlic Allium sativum, p. 110-157. In: H.D. Rabinowitch and J.L. Brewster (eds.). Onions and allied crops. CRC Press, Boca Raton, FL.

Tattelman, E. 2005. Health effects of garlic. Amer. Fam. Physician 72:103-106.

Villalobos, F.J., L. Testi, R. Rizzalli, and F. Orgaz. 2004. Evapotranspiration and crop coefficients of irrigated garlic (Allium sativum L.) in a semi-arid climate. Agr. Water Mgt. 64:233-249.

Volder, A., R.M. Gifford, and J.R. Evans. 2007. Effects of elevated atmospheric $\mathrm{CO}_{2}$, cutting frequency, and differential day/night atmospheric warming on root growth and turnover of Phalaris swards. Glob. Change Biol. 13:1040-1052.
Vu, J.C.V., L.H. Allen, K.J. Boote, and G. Bowes. 2008. Effects of elevated $\mathrm{CO}_{2}$ and temperature on photosynthesis and Rubisco in rice and soybean. Plant Cell Environ. 20:68-76.

Wheeler, T.R., A.J. Daymond, J.I.L. Morison, R.H. Ellis, and P. Hadley. 2004. Acclimation of photosynthesis to elevated $\mathrm{CO}_{2}$ in onion (Allium cepa) grown at a range of temperatures. Ann. Appl. Biol. 144:103-111.

Wullschleger, S.D. 1993. Biochemical limitations to carbon assimilation in $\mathrm{C}_{3}$ plants - $\mathrm{A}$ retrospective analysis of the $\mathrm{A} / \mathrm{C}_{\mathrm{i}}$ curves from 109 species. J. Expt. Bot. 44:907-920.

$\mathrm{Xu}, \mathrm{Z}$., G. Zhou, and Y. Wang. 2007. Combined effects of elevated $\mathrm{CO}_{2}$ and soil drought on carbon and nitrogen allocation of the desert shrub Caragana intermedia. Plant Soil 301:87-97.

Ziska, L.H. and J.A. Bunce. 2006. Plant responses to rising atmospheric carbon dioxide, p. 17-47. In: J.I.L. Morison and M.D. Morecroft (eds.). Plant growth and climate change. Blackwell Publ., Oxford, UK.

Ziska, L.H., J.A. Bunce, H. Shimono, D.R. Gealy, J.T. Baker, P.C.D. Newton, M.P. Reynolds, K.S.V. Jagadish, C. Zhu, M. Howden, and L.T. Wilson. 2012. Food security and climate change: On the potential to adapt global crop production by active selection to rising atmospheric carbon dioxide. Proc. Biol. Sci. 279:4097-4105. 